To Maega $\mid$ Jurnal Pengabdian Masyarakat

Agustus 2021, Vol. 4, No. 2, hal 179-186

$\operatorname{ISSN}(P): 2622-6332 ; \operatorname{ISSN}(E): 2622-6340$

http://www.ojs.unanda.ac.id/index.php/tomaega

\title{
Pendidikan Dini Prinsip Edukasi Kesehatan Gizi Seimbang melalui metode Kids Play and Care
}

\author{
Salmon Charles Pardomuan Tua Siahaan ${ }^{1 *}$, Natalia Yuwono ${ }^{1}$, Susanto ${ }^{1}$, Nimas \\ Pristiwanto ${ }^{1}$ \\ ${ }^{1}$ Program Studi Kedokteran, Fakultas Kedokteran, Universitas Ciputra Surabaya, Indonesia \\ *Correspondent Email: $\underline{\text { charles.siahaan@ciputra.ac.id }}$
}

Article History:

Received: 05-05-2021; Received in Revised: 28-05-2021; Accepted: 06-06-2021

DOI: http://dx.doi.org/10.35914/tomaega.v4i2.743

\begin{abstract}
Abstrak
Gizi seimbang merupakan rangkaian konsumsi zat gizi secara seimbang, beranekaragam dengan jumlah yang sesuai dengan kebutuhan tubuh, serta memperhatikan agar beraktifitas fisik minimal 30 menit setiap hari, berperilaku hidup bersih, pemantauan berat badan secara teratur serta minum air putih 8 gelas sehari. Edukasi gizi seimbang semenjak usia dini sangat berguna agar meningkatkan kesadaran akan pentingnya memakan makanan dengan keanekaragaman gizi dan aktifitas fisik sebagai upaya menjaga kesehatan jasmani. Pengabdian masyarakat ini bertujuan untuk menumbuhkan kebiasaan makan makanan bergizi dan hidup bersih dan higienis seperti cuci tangan enam langkah sebelum makan untuk mencegah penularan penyakit. Metode pelaksanaan dengan diskusi dua arah sehingga dapat memicu keaktifan siswa-siswi, kemudian diberikan penjelasan singkat oleh ahli Kesehatan. Siswa-siswi juga diajak untuk ikut aktif dalam permainan yang dipergakan, kegiatan juga dilakukan dalam kelompok, untuk mengajarkan megenai pentingnya bekerja sama. Siswa-siswi yang aktif dan mendapatkan nilai terbanyak akan mendapatkan reward. Penyuluhan gizi seimbang pada anak sekolah dasar berjalan lancar, seluruh peserta antusias dalam mengikuti kegiatan ini.
\end{abstract}

Kata Kunci: Penyuluhan, Gizi Seimbang, Anak Sekolah, Cuci Tangan

\begin{abstract}
Balanced nutrition is a series of nutritional consumption in a balanced, varied and appropriate amount to the body's needs, and paying attention to physical activity for at least 30 minutes every day, having a clean lifestyle, monitoring body weight regularly and drinking 8 glasses of water a day. Education on Balanced nutrition from an early age is primely to increase awareness about the importance of eating foods with a variety of nutrients and physical activity as an effort to maintain personal and physical health. This community service aims to foster a habit of eating nutritious food and living a clean and hygienic life such as washing hands six steps before eating to prevent disease transmission. Implementation method with two-way discussion so that it can trigger the activeness of students, we invite some health experts to explain the aim of healthy life. Students invited to join in the games dan the games conduction group basis, so studenst also learn about the importance of cooperating works. Students who are active and get the most scores will get rewards. Counseling on balanced nutrition to elementary school children went well, all participants were enthusiastic in participating in this activity.
\end{abstract}

Keywords: Counseling, Balanced Nutrition, School Children, Washing Hands 
[ 180 ] Salmon Charles Pardomuan Tua Siahaan, dkk / To Maega : Jurnal Pengabdian Masyarakat, Vol.4; No.2; Agustus 2021

\section{Pendahuluan}

Ketidakseimbangan gizi atau dikenal dengan nutritional imbalance merupakan ketidakseimbangan antara keluaran dan asupan zat gizi, baik asupan yang melebihi dari luaran ataupun sebaliknya. Dampak ketidakseimbangan zat gizi ini menyebabkan sebagian besar masalah gizi anak. Sustainable Development Goals atau dikenal dengan SDGs dicanangkan sejak 2015 memiliki 17 tujuan yang harus dicapai pada tahun 2030. Tujuan nomor dua dari 17 tujuan SDGs adalah "Tanpa Kelaparan", yang berarti menghilangkan kelaparan, mencapai ketahanan pangan dan Gizi yang baik, serta meningkatkan pertanian berkelanjutan, dimana status gizi anak merupakan salah satu indikator Kesehatan yang dipantau. Tujuan ini termasuk kedalam salah satu pilar pembangunan sosial Indonesia (Bappenas, 2020; WHO, 2018)

Data Riset Kesehatan Dasar Indonesia tahun 2018 menunjukkan bahwa pada anak Indonesia umur 5-12 tahun prevalensi sangat pendek sebanyak 6,7\%, prevalensi pendek $16,9 \%$, prevalensi sangat kurus $2,4 \%$, prevalensi kurus $6,8 \%$, gemuk $10,8 \%$ dan obesitas sebanyak 9,2\% (RI, 2019). Anak-anak merupakan kelompok yang paling rentang terhadap ancaman Kesehatan serta gizi dan setiap perubahan dalam tumbuh kembangnya dapat berdampak pada perkembangan ekonomi sosial secara keseluruhan. Dampak lebih luasnya adalah jika gizi pada masa kanak-kanan tidak memadai maka dapat berdampak negatif terhadap sekolah mereka, sehingga menurunkan pendapatan saat dewasa yang pada akhirnya berdampak negative bagi pembangunan berkelanjutan jangka Panjang nasional. Status Gizi yang baik dapat meningkatkan kecerdasan anak dengan meningkatkan daya konsentrasi, kemampuan berpikir dan tentunya meningkatkan produktifitas kerja di masa mendatang (Sa'adah dkk., 2014; Hasdianah dkk., 2014; Pramono dkk, n.d.).

Jumlah dan jenis makanan serta minuman berperan dalam asupan gizi individu. Asupan gizi yang optimal sangat penting untuk pertumbuhan, perkembangan fisik serta kecerdasan individu di seluruh kelompok umur, terutama bayi dan anak-anak. Asupan gizi yang baik membuat individu lebih sehat, tidak mudah terkena penyakit infeksi maupun non-infeksi, produktifitas meningkat serta mengurangi risiko dari penyakit kronis dan kematian dini (Kemenkes RI, 2014).

Kualitas edukasi berperan penting dalam perkembangan ekonomi, sosial dan politik suatu negara. Tidak cukup hanya memasukkan anak ke dalam sekolah, tetapi perlu juga bagi anak-anak agar mendapatkan pengetahuan dan kemampuan dasar yang diperlukan bagi kesejahteraan pribadi. Sekolah dasar merupakan fase penting dalam perkembangan kesadaran dan kepribadian anak. Nutrisi merupakan komponen penting dalam Kesehatan, kehidupan serta perkembangan otak manusia. Setiap anak memiliki hak untuk mendapatkan Pendidikan baik formal dan non formal termasuk dalam pendidikan Kesehatan dini. Nutrisi yang seimbang sangat vital untuk ketahanan, pertumbuhan fisik, perkemgbangan kognitif dan produktivitas manusia. Permasalahan gizi dapat mempengaruhi kemampuan belajar anak dan menyebabkan prestasi anak menjadi rendah di sekolah (Asmare dkk., 2018; Putri dkk., 2020) 
[ 181 ] Salmon Charles Pardomuan Tua Siahaan, dkk / To Maega : Jurnal Pengabdian Masyarakat, Vol.4; No.2; Agustus 2021

Malnutrisi, baik gizi kurang maupun lebih, dapat dipengaruhi oleh beberapa aspek, antara lain genetik, sosial ekonomi, demografi, tingkat pengetahuan, tempat tinggal, higienitas dan sanitasi serta gaya hidup dari penduduk tersebut (Rachmi dkk., 2017). Dalam rangka menanggulangi permasalahan gizi pada anak sekolah dasar di Kecamatan Made, intervensi gizi berupa bimbingan mengenai gizi seimbang dapat dilakukan sebagai langkah awal. Gizi seimbang merupakan rangakaian konsumsi pangan setiap hari yang memiliki zat gizi dalam tipe serta jumlah yang sesuai dengan kebutuhan badan, dengan memperhatikan prinsip keanekaragaman pangan, beraktifitas fisik, berperilaku hidup bersih serta mempertahankan berat tubuh wajar untuk menghindari permasalahan gizi (Palupi, 2018; Kemenkes RI, 2014; Popkin dkk., 2012).

Padatnya populasi di Indonesia mempengaruhi kualitas dan Pendidikan serta kesehatan di Indonesia, terutama anak-anak yang berada dalam masa pertumbuhan. Maka dari itu, mereka adalah penentu kemajuan masa depan bangsa dan negara Indonesia. Persiapan lingkungan agar dapat mempengaruhi perilaku pemenuhan gizi seimbang bagi anak usia sekolah sangat diperlukan peran dari tenaga kesehatan, sekolah, guru dan orang tua (Dwi dkk., 2016; Wiradnyani dkk., 2019)

Minimnya kepedulian organisasi maupun mahasiswa akan kesehatan dan pendidikan anak-anak di Indonesia, kami anggota Swayanaka Indonesia regional Universitas Ciputra bertujuan mengadakan kegiatan sosial "Kids Play and Care". Kegiatan ini adalah bentuk kepedulian terhadap anak-anak tentang kesehatan terutama anak-anak yang dalam masa pertumbuhan. Melalui kegiatan belajar bersama yang disertai dengan bermain sehingga anak-anak lebih fokus dan tidak membosankan. Materi yang akan kami berikan kami sesuiakan dengan kebutuhan pengetahuan anakanak era industri 4.0.

\section{Metode}

Kegatan pengabdian masyarakat ini diadakan di SDN Made I Surabaya, jumlah responden yaitu empat puluh siswa dan siswi kelas empat SD. Kegiatan ini akan mengadakan hibrida antara kesehatan dan pendidikan di mana akan ada materi-materi tentang kesehatan tubuh manusia disertai dengan games yang menarik. Metode yang kami gunakan yaitu pendidikan masyarakat, dimana siswa-siswi menerima materi untuk meningkatkan pemahaman. Kami menyusun kurikulum yakni dalam setiap bulannya akan berbeda topik kesehatan. Semacam blok pada perkuliahan kedokteran di FKUC, sehingga siswa-siswi tidak merasa bosan dan kegiatan berjalan secara follow up. Siswasiswi yang aktif bertanya dalam sesi materi akan mendapatkan reward berupa alat tulis. Setiap kunjungan, kami akan memberikan notes kecil untuk setiap siswa, berfungsi sebagai catatan dan rapor penilaian.

Setiap acara berakhir, kami akan menarik kembali notes tersebut untuk diberikan penilaian, rapor ini berfungsi untuk pengumpulan nilai, siswa atau siswi yang mendapatkan jumlah nilai tertinggi akan dijadikan duta dokter cilik 2019. Setiap materi kesehatan akan diisi oleh pemateri dari dosen FKUC, sehingga akan ditampilkan materi dengan powerpoint. Kegiatan bersifat diskusi dua arah dan ceramah sehingga dapat CTo Maega / Jurnal Pengabdian Masyarakat. This is an open access article under the CC BY-SA 4.0 license (https://creativecommons.org/licenses/by-sa/4.0/). 
[ 182 ] Salmon Charles Pardomuan Tua Siahaan, dkk / To Maega : Jurnal Pengabdian Masyarakat, Vol.4; No.2; Agustus 2021

memicu keaktifan siswa-siswi. Siswa-siswi yang aktif dan mendapatkan nilai terbanyak akan mendapatkan reward dan ditunjuk sebagai duta dokter cilik.

\section{Hasil dan Pembahasan}

Kegiatan pengabdian ini dilakukan oleh 12 Mahasiswa dan 2 Dosen Program Studi Kedokteran Universitas Ciputra. Kegiatan edukasi ini bertujuan untuk menanamkan kebiasaan gaya hidup sehat sejak dini seperti gemar memakan makanan sehat dengan gizi seimbang, seperti sayur dan buah-buahan agar tidak terjadi kekurangan energi dan protein. Disamping itu, menumbuhkan kebiasaan hidup bersih dan higienis seperti cuci tangan enam langkah sebelum makan untuk mencegah penularan penyakit.

Kegiatan diselenggarakan pada tanggal 11 Januari 2020 dan dihadiri oleh siswasiswi kelas 4 SD terdiri dari kelas 4A dan 4B dari Sekolah Dasar Made 1 Surabaya. Acara ini dimulai pada pukul 10.00 WIB sampai pukul 12.00 WIB. Penyuluhan pertama mengenai gizi seimbang kemudian penyuluhan kedua adalah cara mencuci tangan yang baik dan benar yang disampaikan oleh Dosen Fakultas Kedokteran Universitas Ciputra. Tampak siswa-siswi sangat antusias mengikuti penyuluhan dari awal sampai akhir. Penyuluhan menggunakan slide dan video animasi untuk memudahkan pemahaman siswa-siswi. Setelah penyuluhan, panitia Swayanaka UC juga mengadakan mini games. Gunanya untuk mengingat materi yang telah disampaikan. Permainan yang diselenggarakan adalah siswa-siswi diminta untuk mengisi piramida gizi seimbang dengan gambar-gambar makanan yang tersedia. Siswa-siswi dapat menyelesaikan permainan dengan benar sehingga tampak mereka mendengarkan materi dengan baik. Selain itu, siswa-siswi juga dapat mempraktikkan cuci tangan 6 langkah dengan benar.

Konsumsi makanan Gizi seimbang harus beranekaragam atau bervariasi dan terbebas dari bahan-bahan pengawet, pewarna, dan pemanis buatan. Tidak hanya gizi, konsumsi air minum minimal 8 gelas sehari, beraktivitas fisik minimal 30 menit, berperilaku bersih serta pemantauan berat badan ideal pun sangat berpengaruh pada gaya hidup sehat. Kandungan makanan dengan gizi yang seimbang akan memenuhi kebutuhan tubuh individu serta aktivitasnya. Anak usia sekolah mengalami pertumbuhan fisik, kecerdasan kognitif, mental dan emosional yang sangat cepat. Tumbuh kembang tidak hanya memerlukan energi tetapi juga vitamin, mineral serta asam amino yang penting. Pertumbuhan dan perkembangan otak serta sistem saraf pada masa kanak-kanak membutuhkan keseimbangan zat gizi mikronutrien, terutama zat besi, vitamin B12 dan asam lemak omega-3 yang cukup.

Apabila anak menderita kekurangan gizi, maka akan terjadi gangguan pertumbuhan dan perkembangan yang dapat menurunkan kecerdasan dan performa anak. Pada anak yang menderita gizi berlebih dapat terjadi peningkatan risiko terkena penyakit kardiovaskular, gangguan toleransi glukosa, resistensi insulin hingga diabetes mellitus tipe 2, gangguan pada pernapasan, gangguan pada system musculoskeletal dan persendian serta penyakit pada liver, kadung empedu dan GERD (CDC, 2021). Oleh (O)To Maega / Jurnal Pengabdian Masyarakat. This is an open access article under the CC BY-SA 4.O license (https://creativecommons.org/licenses/by-sa/4.0/). 
[ 183 ] Salmon Charles Pardomuan Tua Siahaan, dkk / To Maega : Jurnal Pengabdian Masyarakat, Vol.4; No.2; Agustus 2021

karena itu, mengonsumsi makanan yang dengan prinsip gizi seimbang secara teratur, akan menjadikan anak tumbuh dengan sehat sehingga mampu mencapai prestasi belajar baik serta bugar dalam mengikuti semua aktivitas. Hal ini akan membuat sumber daya manusia yang berkualitas menjadi generasi penerus bangsa yang baik.

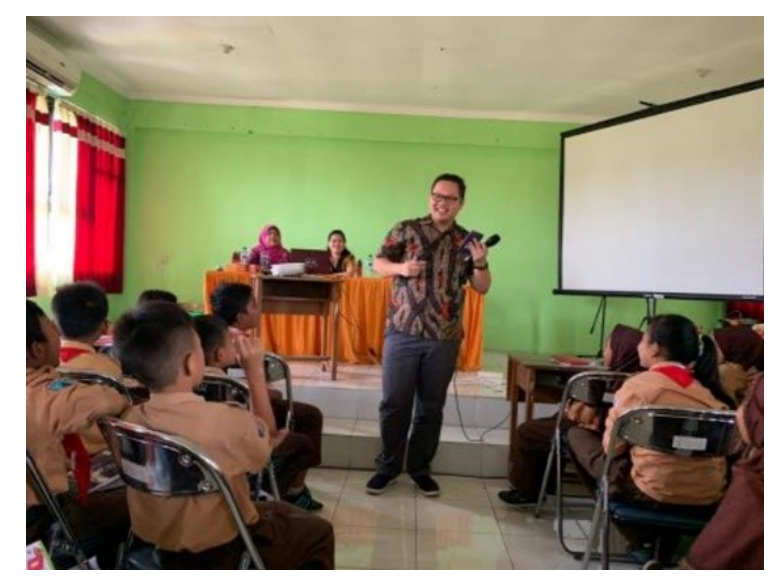

Gambar 1. Pemberian Edukasi Gizi Seimbang dengan metode ceramah

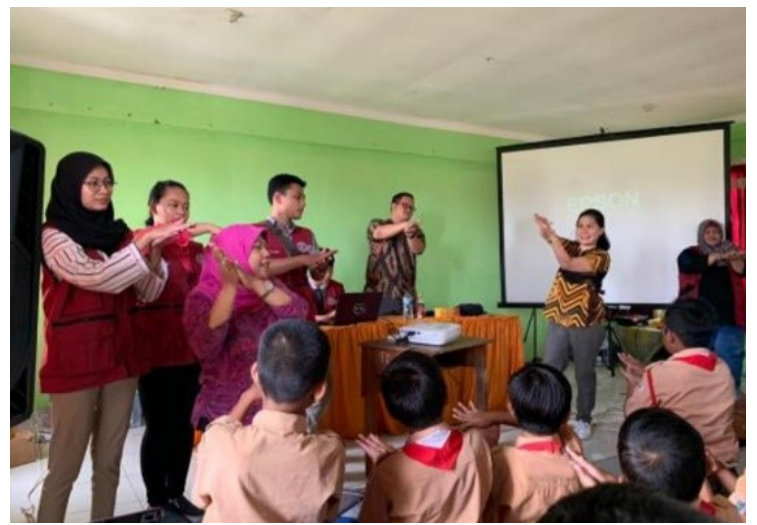

Gambar 2. Edukasi dan praktik cuci tangan 6 langkah sesuai WHO

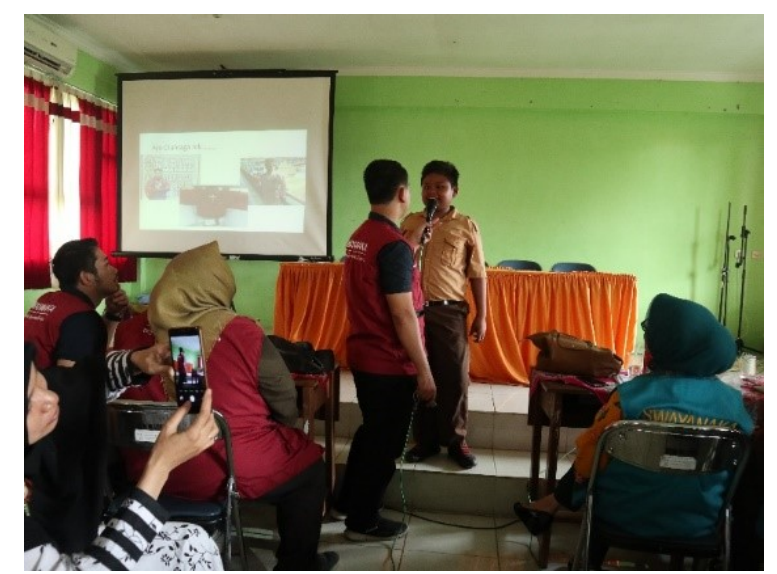

Gambar 3. Menunjuk siswa untuk menjawab pertanyaan terkait materi 
[ 184 ] Salmon Charles Pardomuan Tua Siahaan, dkk / To Maega : Jurnal Pengabdian Masyarakat, Vol.4; No.2; Agustus 2021

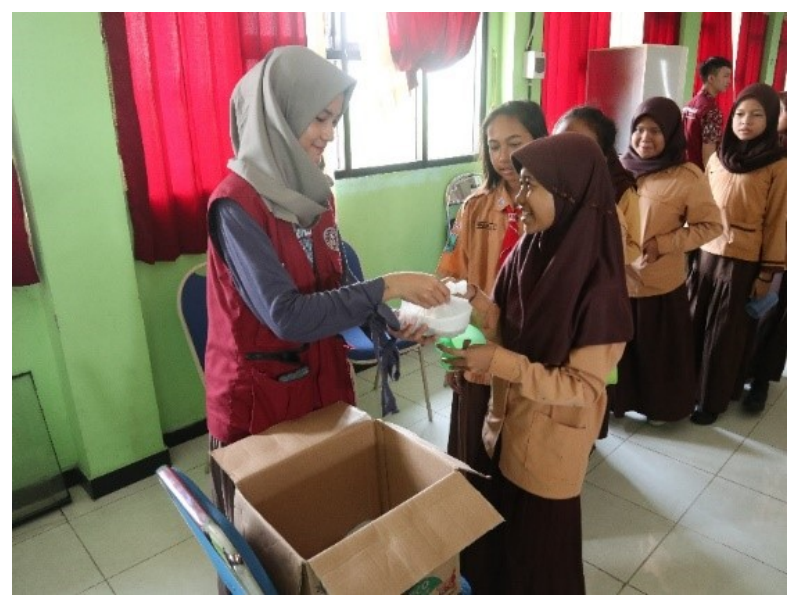

Gambar 4. Membagikan konsumsi kepada siswa-siwi berupa bubur kacang hijau dan telur rebus

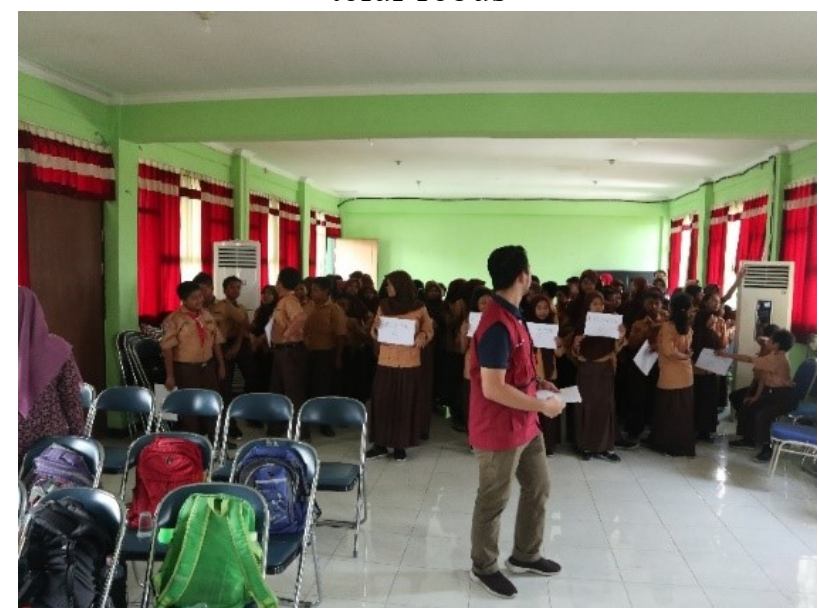

Gambar 5. Mini games pada siswa-siswi

\section{Kesimpulan}

Kegiatan pengabdian masyarakat yang dilaksanakan di SDN 1 Made Surabaya dengan tema "Kids Play and Care - Edukasi Gizi Seimbang dan Cuci Tangan" berjalan dengan lancar dan peserta sangat antusias. Peningkatan pemahaman siswa siswi maupun guru sekolah SDN 1 Made Surabaya terjadi melalui kegiatan ini. Penulis menyarankan adanya kegiatan lanjutan terkait penerapan konsumsi gizi seimbang oleh siswa siswi SDN 1 Made Surabaya. 
[ 185 ] Salmon Charles Pardomuan Tua Siahaan, dkk / To Maega : Jurnal Pengabdian Masyarakat, Vol.4; No.2; Agustus 2021

\section{Ucapan Terimakasih}

Ucapan banyak terima kasih kami tujukan kepada pihak sekolah SDN 1 Made yang telah memberikan ijin serta mendukung kami dalam penyelenggaraan kegiatan pengabdian masyarakat ini. Terima kasih juga tidak lupa kami sampaikan kepada LPPM Universitas Ciputra Surabaya yang telah memberikan dukungan dan kepada jurnal TO Maega yang sudah berkenan mempuplikasikan jurnal ini beserta pihak-pihak yang telah membantu pelaksanaan pengabdian masyarakat ini.

\section{Daftar Pustaka}

Asmare, B., Taddele, M., Berihun, S., \& Wagnew, F. (2018). Nutritional status and correlation with academic performance among primary school children, northwest Ethiopia. BMC Research Notes, 11(1). https://doi.org/10.1186/s13104-018-3909-1

Bappenas. (2020). Metadata Indikator Pilar Pembangunan Sosial Pelaksanaan Pencapaian Tujuan Pembangunan Berkelanjutan/ Sustainable Development Goals (TBP/SDGs) (2nd ed.). Bappenas.

CDC. (2021). Childhood Obesity Causes \& Consequences. Https://Www.Cdc.Gov/Obesity/Childhood/Causes.Html\#: :Text=Consequences of Obesity,-More Immediate Health\&text=Children Who Have Obesity Are More Likely to Have\%3A\&text=High Blood Pressure and High,as Asthma and Sleep Apnea.

Citra Palupi, K. (2018). Edukasi Gizi Seimbang Pada Anak Sekolah Dasar Di Kecamatan Cilincing Jakarta Utara. In Jakarta Utara Jurnal Abdimas (Vol. 5, Issue 1).

Dwi, L., Yanti, U., \& Suyanto, E. (2016). Gambaran Status Gizi Dan Asupan Zat Gizi Pada Siswa Sekolah Dasar Kecamatan Sungai Sembilan Kota Dumai. In JOM FK (Vol. 3, Issue 1).

Hayatus Sa'adah, R., Herman, R. B., \& Sastri, S. (2014). Hubungan Status Gizi dengan Prestasi Belajar Siswa Sekolah Dasar Negeri 01 Guguk Malintang Kota Padangpanjang. In Jurnal Kesehatan Andalas (Vol. 3, Issue 3). http://jurnal.fk.unand.ac.id

Hasdianah, S Siyoto, \& Y Peristyowati. (2014). Gizi, pemanfaatan gizi, diet, dan obesitas. Nuha Medika, 24-42.

Kemenkes RI. (2014). Peraturan Menteri Kesehatan Republik Indonesia Nomor 41 Tahun 2014.

Luh Ade Ari Wiradnyani, Indriya Laras Pramesthi, Maya Raiyan, Siti Nuraliffah, Nurjanatun, Judhiastuty Februhartanty, Evi Ermayani, \& Dwi Nastiti Iswarawanti. (2019). Gizi dan Kesehatan Anak Usia Sekolah Dasar (2nd ed.).

Popkin, B. M., Adair, L. S., \& Ng, S. W. (2012). Global nutrition transition and the pandemic of obesity in developing countries. Nutrition Reviews, 70(1), 3-21. https://doi.org/10.1111/j.1753-4887.2011.00456.x

Pramono, A., Puruhita, N., \& Fatimah Muis, S. (n.d.). Pengaruh pendidikan gizi terhadap pengetahuan dan sikap tentang gizi anak Sekolah Dasar. 
[ 186 ] Salmon Charles Pardomuan Tua Siahaan, dkk / To Maega : Jurnal Pengabdian Masyarakat, Vol.4; No.2; Agustus 2021

Putri, E. A., Hariyanto, E., Sunaryo, T., \& Hisyam, C. J. (2020). Pelatihan Peningkatan Kompetensi Mengajar Bagi Petugas Lembaga Pembinaan Khusus Anak (LPKA) Tangerang, Banten. To Maega | Jurnal Pengabdian Masyarakat, 3(1), 36. https://doi.org/10.35914/tomaega.v3i1.304

Rachmi, C. N., Li, M., \& Alison Baur, L. (2017). Overweight and obesity in Indonesia: prevalence and risk factors - a literature review. In Public Health (Vol. 147, pp. 20-29). Elsevier B.V. https://doi.org/10.1016/j.puhe.2017.02.002

WHO. (2018). Global Reference List of 100 Core Health Indicators (plus health-related SDGs). WHO : World Health Organization 